\title{
The influence of economic factors on rights issue announcements
}

\section{INTRODUCTION}

International and local researchers have all found that there is a significant negative share price response to the announcement of a rights issue (White and Lusztig, 1980; Asquith and Mullins, 1986; Mikkelson and Partch, 1986; Smith, 1986; Dierkens, 1991; Pilotte, 1992; Youds, Firer and Ward, 1993; Bayless, 1994; Sant and Ferris 1994; Bohren, Eckbo and Michalsen, 1997; Bhana, 1998 and Horne, 1999).

This study investigates a number of economic factors to determine whether individually or collectively they affect the share price response to a rights issue announcement on the JSE. It adds to the existing body of literature on new equity issue announcements and it will assist issuing firms and investors in obtaining a better understanding of what influences the valuation of shares when undertaking new equity issuances.

\section{LITERATURE REVIEW}

A number of studies have focused on explaining the negative share price response to rights issue announcements. The majority of the findings in this area have produced information models (Myers and Majluf, 1984; Miller and Rock, 1985 and Asquith and Mullins, 1986) and management theories (Jensen and Meckling, 1976; Downes and Heinkel, 1982 and Masulis and Korwar, 1985).

More recently, researchers focused on finding explanations for the variances within the negative share price responses. They focused on firm-specific factors, which included the application of funds, capital structure, issue size, information asymmetry, growth opportunities and managerial ownership (McConnell and Mascarella, 1985; Masulis and Korwar, 1986; Asquith and Mullins, 1986; Mikkelson and Partch, 1986; Youds, Firer and Ward, 1993; Bhana, 1998 and Korajczyk and Levy, 2001).

Economic factors have been found to explain some of the variance and have been linked to other issues surrounding rights issue announcements (Myers and Majluf, 1984; Asquith and Mullins, 1986; Chen, Roll and Ross, 1986; Hansen and Crutchely, 1990; Korajczyk, Lucas and McDonald, 1991; Lee, 1992; Bayless and Chaplinsky, 1993; Choe, Masulis and Nanda, 1993; Balduzzi, 1995; Gjerde and Saettem, 1999; van Rensberg, 1999 and Korajczyk and Levy, 2001).

*Wits Business School, University of the Witwatersrand, PO Box 98, Wits 2050 Republic of South Africa.

Email: mike.ward@up.ac.za
Madura and Akhigbe (1995), in their study of the effect of economic factors on the valuation effects of convertible debt offerings, found a significant relationship between the share price response and nominal interest rates; the relative stock price level of the issuing firm, and economic growth.

Although several researchers have identified significant relationships between interest rate changes and share returns, volatility and cash flow (Nofsinger, 2001; Henn and Smit, 1997; Harvey and Huang, 1991; Lobo, 2000; Chen, Roll, and Ross, 1986; Balduzzi, 1995; Van Rensberg, 1999; Lee, 1992; Gjerde and Saettem, 1999 and Madura and Akhigbe, 1995), Choe et al. (1993) found that neither long-term nor short-term interest rates had any significant power to explain the share price reaction to the announcement of an equity issuance.

Theoretical models derived from the asymmetric information models of Myers and Majluf (1984), Lucas and McDonald (1990), Korajczyk et al. (1991), and Choe et al. (1993) explain that periods of high economic growth are also periods of low asymmetric information, which accounts for the clustering of equity issues in periods of strong economic growth. Periods of low asymmetric information are associated with lower adverse selection costs, as investment opportunities are more promising and there is less uncertainty about the assets in place.

In South Africa, Horne (1999) found that a three-month moving average of the five-day average cumulative residual returns subsequent to a rights issue announcement could be plotted against time to reveal hot, cold and normal periods in the market. $\mathrm{He}$ suggested that there could be external determinants for the above periods. Bayless and Chapinsky (1996) focused on finding periods in which equity could be raised at favourable terms, using the aggregate volume of equity issues as their main focal point. Their findings seemed to suggest that macroeconomic conditions are unrelated to share price responses, but they qualify their findings by stating, "However, it should be stressed that these results do not imply that macroeconomic factors are unimportant influences on investor's expectations of the motivation to issue. Indeed the significant differences in economic conditions in hot and cold markets amply demonstrate the need to control for the influence of market and macroeconomic conditions on the announcement date prediction errors." (Bayless and Chapinsky, 1996:265).

Taggart (1977), Marsh (1982), Bayless and Chaplinsky (1993), Asquith and Mullins (1986), Hansen and Crutchley (1990), and Korajczyk et al. (1991) all reported that equity issues tend to follow strong equity market 
performance and that the decision to issue equity was positively related to the performance of the stock price of the firm relative to the market.

Choe et al. (1993) showed that announcement-day price reactions of common stock offerings are less negative for equity issues announced during business cycle expansions. Bayless and Chaplinsky (1996) found a positive coefficient for their variable that captured the change in the Index of Leading Indicators. This showed that the share price response to equity issues was less negative in periods when business conditions were stronger.

The literature clearly demonstrates strong associations between macroeconomic factors and market responses in terms of returns, volatility, cash-flow and trading volume. Research also supports an association between the business cycle and the frequency of rights issue announcements. This study further examines the impact of economic factors on share prices upon the announcement of a rights issue.

\section{HYPOTHESES}

The first hypothesis seeks to confirm the negative share price response to rights issues in the fourteen-year period of data being analysed.

The second hypothesis states that economic factors both individually and collectively influence the impact that rights issue announcements have on share prices.

The following model is used to test the above hypothesis.

$$
\begin{aligned}
\operatorname{CAR}_{\mathrm{i}}= & \alpha_{0}+\alpha_{1} \Delta \mathrm{INT}_{\mathrm{i}}+\alpha_{2} \text { STÖCK }_{\mathrm{i}}+ \\
& \alpha_{3} \mathrm{ECON}_{\mathrm{i}}+\alpha_{4} \text { CYCLE }_{\mathrm{i}}+\alpha_{5} \mathrm{CON}^{+} \mathrm{NFI}_{\mathrm{i}}
\end{aligned}
$$

where

$$
\begin{aligned}
\mathrm{CAR}_{\mathrm{i}}= & \begin{array}{l}
\text { the cumulative abnormal return of rights } \\
\text { issue } \mathrm{i} \text { over the event window }
\end{array} \\
\alpha_{1-5}= & \begin{array}{l}
\text { regression coefficients to be calculated for } \\
\text { each independent variable }
\end{array}
\end{aligned}
$$

$\Delta \mathrm{INT}_{\mathrm{i}}=$ interest rate proxy, measured as the percentage change of the term lending rate in the 12 months prior to the announcement. The sign of the coefficient is expected to be negative.

STOCK $_{i}=$ stock market performance proxy, measured as the percentage change of the market index in the 12 months prior to the announcement. The sign of the coefficient is expected to be positive.
$\mathrm{ECON}_{\mathrm{i}}=$ economic growth proxy, measured as the actual lagging index of economic indicators less the three-month average on the index all divided by the actual lagging index of economic indicators at the time of the announcement. The sign of the coefficient is expected to be positive.

$\mathrm{CYCLE}_{\mathrm{i}}=$ business cycle proxy, measured using a dummy variable to indicate the phase of the business cycle. One represents an upturn in the business cycle while zero indicates a downturn in the business cycle at the time of the announcement. The sign of the coefficient is expected to be positive.

$\mathrm{CON}_{\mathrm{l}}=$ Business Confidence Index (BCl) proxy, measured as the actual quarterly $\mathrm{BCl}$ compiled by the Bureau of Economic Research less the three-month average of the $\mathrm{BCl}$ all divided by the actual $\mathrm{BCl}$ at the time of the announcement. The sign of the coefficient is expected to be positive.

\section{METHODOLOGY}

The methodology used in this study was based on the event study methodology as described by Bowman (1983) and as used by Madura and Akhigbe (1995) and Bhana (1998).

The abnormal share price reactions are used in the second part of the analysis, which consists of a multiple regression model. The dependent variables in the multiple regression model are the cumulative abnormal returns and the independent variables are the economic factors identified in the literature review. A 5\% significance level is used.

The research population consists of all rights issue announcements by companies listed on the JSE. The sample used for this study is all those rights issues made by companies during the period 1 January 1989 to 31 December 2002 (see Figure 1).

For an observation to be accepted in the sample data, it had to meet the criteria listed below. (A detailed list of exclusions is available on request from the authors).

a) The sample was restricted to ordinary shares.

b) Only rights issues that were for shares in the issuing company were included.

c) The sample was restricted to those companies that have Rand-denominated share prices.

d) McWilliams and Siegel (1997) suggest that the following list of events would be classified as confounding events: announcements of an impending merger; signing of a major government 
contract; announcement of a new product; and the filing of a large damage suit. Simultaneous announcement of interim or annual financial results were also found to be confounding events and these observations were excluded.

e) Rights issue announcements that were anticipated prior to their initial announcement in the press, or on SENS were excluded from the sample. f) Announcements that have less than 30 daily returns (share price movements) in their estimation period and in the 20 days surrounding the announcement were excluded from the sample.

g) Announcements that had no trading days during the event window were excluded from the sample because the share price reaction to the announcement cannot be measured.

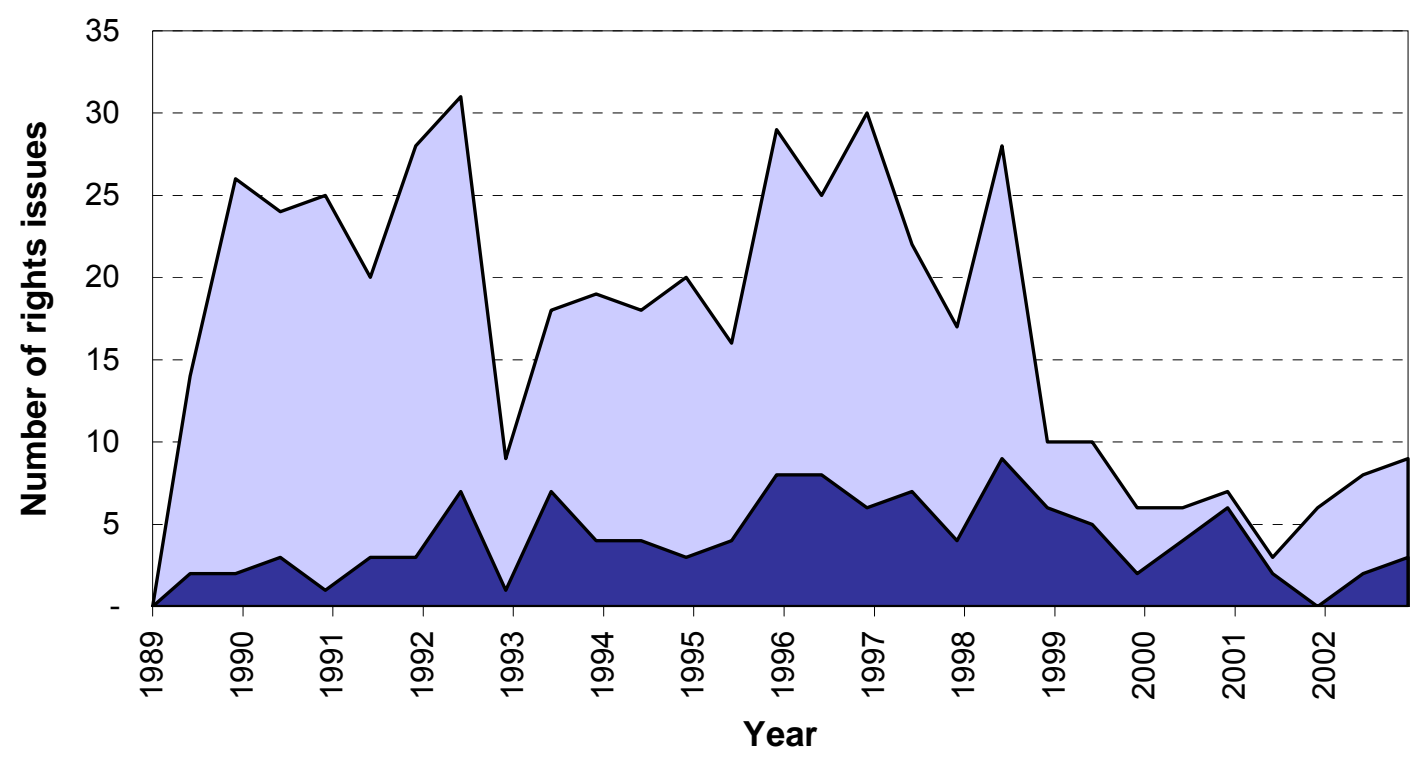

$\square$ Initial Sample

$\square$ Final Sample

Figure 1: Rights issue announcements included in the final sample

\section{DATA SPECIFICATIONS AND COLLECTION}

Rights issues held between the period 1 January 1989 and 31 December 2002 were identified from the JSE December 1997 and 2002 bulletins. For those rights issues that had not already been excluded, the announcement date was established by inspecting the company records obtained from BFA McGregors. The announcement dates for those rights issues that were held between 1 January 1989 and 31 December 1998 were sourced from Horne (1999).

The daily share and index closing prices were obtained from I-Net Bridge (Pty) Ltd and from BFA McGregors. Alternative data sources were required so that data integrity checks could be conducted.

The following independent variables were obtained from the South African Reserve Bank, I-Net Bridge (Pty) Ltd. or the Bureau for Economic Research:

- term lending base rate for the interest rate proxy (monthly data);
- closing prices for the All-Share index for the stock market performance proxy (daily data);

- lagging index of economic indicators for the economic growth proxy (monthly data);

- business cycle turning point for the business cycle (varied period data);

- business confidence index for the business confidence index proxy (quarterly data).

To improve the reliability of the study, a random sample was taken from each of the specified data that was collected. The items selected were traced to the original source where the amounts, figures, or information were confirmed. These items were then located in another database or relevant source to ensure that the same conclusions were reached. All discrepancies were investigated and errors were rectified. Dramatic share price movements for the entire sample were also investigated to ensure that they were not because of errors or confounding events. 
Secondly, a random sample was taken directly from the source, or sources of each of the specified data. The items selected were traced to the collected data where the amounts, figures, or information were confirmed. All discrepancies were investigated and errors were rectified.

\section{DATA ANALYSIS}

Bowman (1983) notes that the most popular model for calculating abnormal returns in event studies is the market model. The market model is also advocated by McWilliams and Seigel (1997) and McWilliams and McWilliams (2000), and is used by other South African researchers, namely: Youds, Firer and Ward (1993), Bhana (1998), and Horne (1999), and internationally by Mikkelson and Partch (1986), Asquith and Mullins (1986) and Pilotte (1992). However, the simple CAPM pricing models have increasingly been criticised because of their inability to explain a cross-section of expected returns.

Fama and French (1992 and 1996) and Daniel and Titman (1997) suggest that characteristics, including company size, book-to-market ratio, earnings-to-price ratio and leverage, provide better share price return explanations than traditional risk models. Although their research has focused on the United Sates stock market, similar yet mixed results have been found on the JSE (Mutooni, 2001 and Van Rensberg, 2001).

Bowman (1983) found that the mean adjusted returns method was very robust and performed as well or better than other risk controlled portfolio methods in many conditions. Based on the findings of Mordant (2002) and Bowman (1983) it was felt that the results of this study would not be compromised by using the market model to estimate abnormal returns. The event window was kept as short as possible to limit the possible effects, if any, that the above-mentioned factors might cause.

The rate of return on the share price of firm $i$ on day $t$ using the market model is expressed as:

$\mathrm{R}_{\mathrm{it}}=\alpha_{\mathrm{i}}+\beta_{\mathrm{i}} \mathrm{R}_{\mathrm{mt}}+\varepsilon_{\mathrm{it}}$

where

$\mathrm{i}=$ selected firm from rights issue sample data,

$\mathrm{t}=$ the day measured relative to the event date,

$\mathrm{R}_{\mathrm{it}} \quad=$ the rate of return on firm $\mathrm{i}$ for day $\mathrm{t}$,

$\mathrm{R}_{\mathrm{mt}}=$ the market return on the market portfolio represented by the JSE All-Share index for day $t$,

$\beta_{\mathrm{i}} \quad=$ beta, the systematic risk of firm i relative to the market. A constant for stock i, $\alpha_{i} \quad=$ alpha, the intercept of the linear relationship between the returns of firm i relative to the return of the market. A constant for firm i,

$\varepsilon_{\mathrm{it}}=$ the error term (residual) where $\Sigma\left(\varepsilon_{\mathrm{it}}\right)=0$.

The parameters $a_{i}$ and $b_{i}$ are the estimates of $\alpha_{i}$ and $\beta_{i}$ respectively. These market model parameters were estimated using ordinary least square regression over the estimation period that begins 250 trading days before the announcement and ends six trading days before the announcement (Brown and Warner, 1985).

Once $a_{i}$ and $b_{i}$ have been estimated, Equation 2 is manipulated to calculate the residuals as follows:

$\varepsilon_{\text {it }}=R_{\text {it }}-\left(a_{i}+b_{i} R_{m t}\right)$

In Equation 2 it was noted that the expected residuals would be zero; therefore in Equation 3 if $\varepsilon_{i t}$ has a nonzero value then the residual is termed the abnormal return.

The following equation from McWilliams and McWilliams (2000:3) was then used to calculate the cumulative abnormal return $(C A R)$ over the event window for each rights issue.

$\mathrm{CAR}_{\mathrm{i}}=\sum_{\mathrm{t} \varepsilon \mathrm{EW}} \mathrm{AR}_{\mathrm{it}}$

where

$\sum_{t \in E W}=$ the summation of values for each $t$ in the event window,

$A R_{i t}=$ the abnormal return $\left(\varepsilon_{i} t\right)$ as calculated in Equation 3

The average cumulated abnormal return (ACAR) over the event window for all rights issues in the sample is then calculated as follows:

$\operatorname{ACAR}=\frac{1}{n} \sqrt{\frac{T-4}{T-2} \sum_{t=1}^{n} \mathrm{CAR}_{i}}$

where

$\mathrm{CAR}_{\mathrm{i}}=$ the cumulative abnormal return of rights issue $\mathrm{i}$ over the event window, as calculated in Equation 4,

$\mathrm{n}=$ the number of rights issues in the sample,

$\mathrm{T}=$ the number of days in the estimation period.

Before commencing with statistical testing, a number of issues were considered to ensure that the tests used are 
effective and valid. These included non-normality in the daily return data and non-synchronous trading.

To account for serial correlation of daily event-period abnormal returns for the same firm McWilliams and McWilliams (2000) recommended that the cumulative abnormal return for each rights issue is standardised. This is required before the Z-statistic can be calculated.

McWilliams and McWilliams (2000) further note that this assumes that the $\mathrm{CAR}_{\mathrm{i}}$ are independent. This is a reasonable assumption in studies where the event is firm specific as opposed to being a common event date. The Z-statistic then has an approximately standard normal distribution.

Equation 6 (presented below) is used to compute the significance of the abnormal returns on each day in the event window, and on the 10 days surrounding the event window. This is done to establish an appropriate event window. It also helps to identify any possible announcement leakages that may have occurred.

The standard deviation of the $A R_{i t}$ is:

$$
S D_{i t}=S i \sqrt{\frac{1+1}{T}+\frac{\left(\bar{R}_{m t}-R_{m}\right)^{2}}{\sum_{t \in E P}^{n}\left(\bar{R}_{m t}-R_{m}\right)^{2}}}
$$

where

$$
\begin{aligned}
\mathrm{S}_{\mathrm{i}}= & \begin{array}{l}
\text { the standard error of the OLS Market Model } \\
\text { regression for rights issue } \mathrm{i},
\end{array} \\
\mathrm{T}= & \text { the number of days in the estimation period, } \\
\mathrm{R}_{\mathrm{mt}}= & \text { the market return on the market portfolio } \\
& \begin{array}{r}
\text { represented by the JSE All-Share index for } \\
\text { day } \mathrm{t},
\end{array} \\
\overline{\mathrm{R}}_{\mathrm{m}}= & \text { the mean return over the estimation period } \\
& \text { for the firm, } \\
\sum_{\mathrm{t} E \mathrm{EP}}= & \text { the summation of values for each } \mathrm{t} \text { in the } \\
& \text { estimation period. }
\end{aligned}
$$

The abnormal return for each firm can then be standardised according to:

$$
\begin{aligned}
\operatorname{SAR}_{i t} & =\frac{\mathrm{AR}_{\mathrm{it}}}{S D_{i t}} \\
\mathrm{CAR}_{\mathrm{t}} & =\frac{1}{\sqrt{\mathrm{k}}} \sum_{\mathrm{t}=1}^{\mathrm{n}} \mathrm{SAR}_{\mathrm{it}} \\
\mathrm{ACAR} & =\frac{1}{\mathrm{n}} \sqrt{\frac{T-4}{T-2} \sum_{\mathrm{t}=1}^{\mathrm{n}} \mathrm{CAR}_{\mathrm{i}}}
\end{aligned}
$$

The Z-statistic is calculated as follows:

$$
Z=\operatorname{ACAR} \bar{x} \sqrt{n}
$$

McWilliams and McWilliams (2000) found that firmspecific daily abnormal returns tend to follow a skewed distribution. However, they found that the normal distribution was still a good fit for the aggregated Zstatistics used for hypothesis testing. The daily abnormal returns were tested to establish if they were normally distributed. It was found that they were not normally distributed. Nonparametric testing was therefore performed as well as the parametric tests. The Wilcoxon signed rank test was used as suggested by McWilliams and Siegel (1997). This test considers both the sign and magnitude of the abnormal return. McWilliams and Siegel (1997) also recommend the binomial $Z$ statistic. This tests whether the proportion of positive to negative returns exceeds the number expected from the market model. Outliers were excluded from the sample where it could be established that they were the result of a confounding event (McWilliams and Siegel, 1997).

Regression analysis was used to determine whether economic factors are significantly related to the impact of rights issue announcements on share prices. The dependent variable is the average cumulative abnormal returns $\left(A C A R_{i}\right)$ as calculated in Equation 4. The independent variables are the five economic factors identified in the literature review. The independent variables were standardised across the sample.

Regression analysis has a number of assumptions that need to be met before the correctness of the results can be verified:

- $\quad$ Each independent variable (X-axis) in the model was plotted against the dependent variable (Y-axis). These scatter plots were inspected visually to establish that they were linear.

- $\quad$ Tests revealed that heteroscedasticity was present in this study. Since the problem was not acute, no steps to transform the variables were taken.

- $\quad$ Stepwise regression was used to determine which independent variables should be used in the model. A number of different proxies were tested for each economic factor, but only those with the greatest explanatory power were retained for inclusion into the final model.

- The F-test and the $t$-test were used to test the regression model for statistical significance. 


\section{RESULTS}

The sample was tested for daily abnormal returns, covering the period 10 days prior to the announcement to 10 days post the announcement date. The results are presented in Figure 2 and Table 1 . It can be seen in Figure 2 that there is a period of persistent negative daily abnormal returns. Based on these findings, the event window was determined as the announcement day plus the four following days.

Table 1 shows that for the Market Model, the day of the announcement and the day after were both statistically significant in terms of negative abnormal return at the
$5 \%$ significance level using a one-tailed t-test. The average abnormal returns calculated using the Market Adjusted Returns Model in Table 1 show that only the day of the announcement is statistically significant at the $5 \%$ level. The announcement day abnormal return is $3,0 \%$ and $-2,8 \%$ for the Market Model and the Market Adjusted Returns Model respectively.

Figure 2 shows that the results obtained from using the two different estimation methods are visually very similar, with the Market Model return line being consistently below the Market Adjusted Returns Model line.

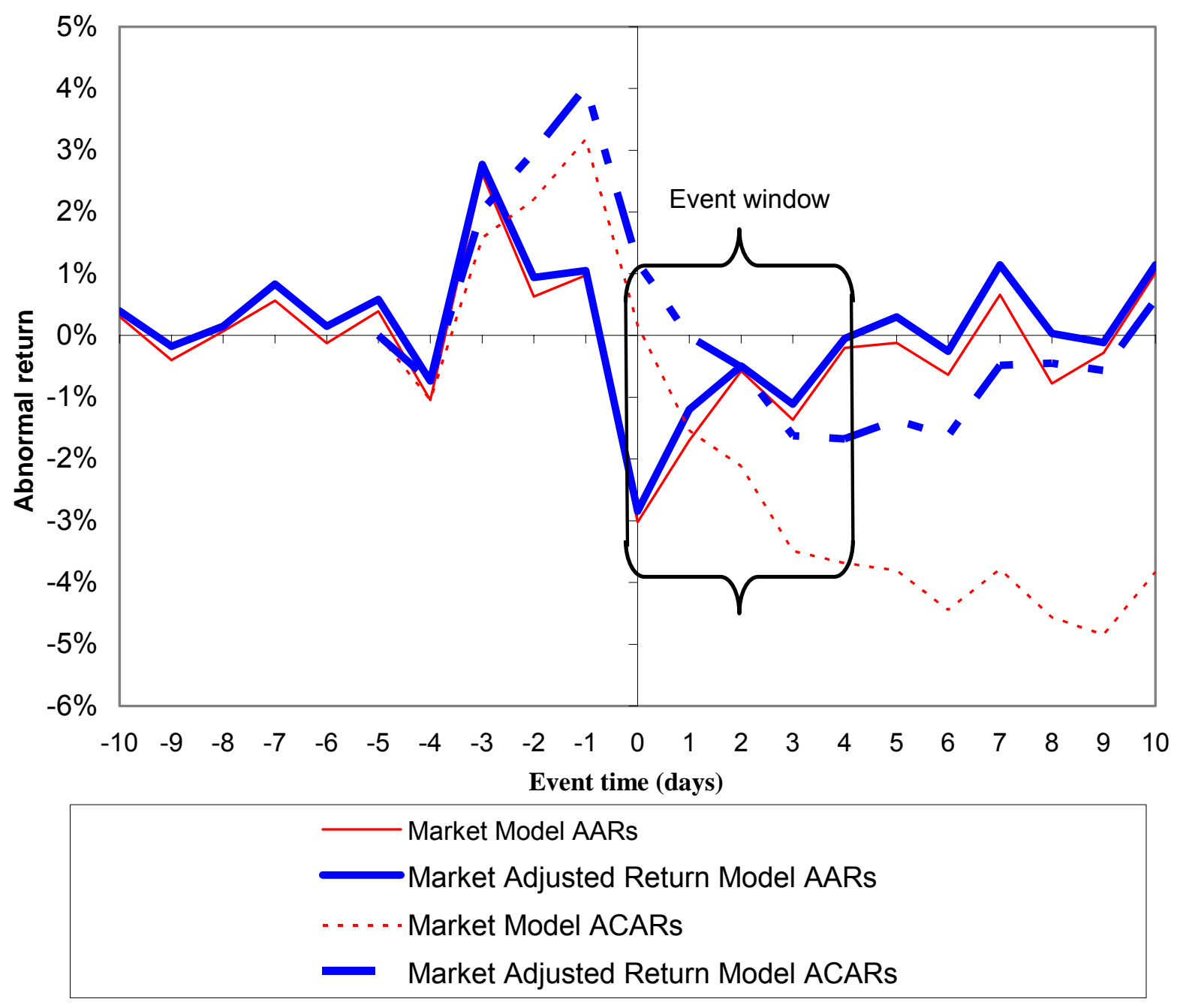

Figure 2: Average abnormal returns and average cumulative abnormal returns from day -5 .

Event study window showing average and average cumulative abnormal returns against both the market model and the market adjusted model. The two models produce similar results, with the negative response clearly visible around day 0 . 
Table 1: The AARs for the 10 days before and after rights issue announcement

\begin{tabular}{ccccc}
\hline & Market model & & \multicolumn{2}{c}{ Market adjusted returns model } \\
\hline Dary & AAR & Z statistic & AAR & Z statistic \\
\hline-10 & $0,3 \%$ & 0,56 & $0,4 \%$ & 0,86 \\
-9 & $-0,4 \%$ & 0,10 & $-0,2 \%$ & 0,62 \\
-8 & $0,1 \%$ & $-0,00$ & $0,1 \%$ & 0,09 \\
-7 & $0,6 \%$ & $-0,33$ & $0,8 \%$ & 0,17 \\
-6 & $-0,1 \%$ & $-0,42$ & $0,1 \%$ & 0,12 \\
-5 & $0,4 \%$ & $-1,10$ & $0,6 \%$ & $-0,46$ \\
-4 & $-1,0 \%$ & $-1,02$ & $-0,7 \%$ & $-0,25$ \\
-3 & $2,6 \%$ & $-0,03$ & $2,8 \%$ & 0,39 \\
-2 & $0,6 \%$ & 1,25 & $0,9 \%$ & 1,69 \\
-1 & $1,0 \%$ & 0,94 & $1,1 \%$ & 1,28 \\
0 & $-3,0 \%$ & $-2,8 \%$ & $-5,28 * \star *$ \\
1 & $-1,7 \%$ & $-1,64^{\star \star *}$ & $-1,42$ \\
2 & $-0,6 \%$ & $-2,26^{* *}$ & $-0,5 \%$ & $-1,29$ \\
3 & $-1,4 \%$ & $-1,37$ & $-1,1 \%$ & $-1,43$ \\
4 & $-0,2 \%$ & $-1,76^{*}$ & $-0,1 \%$ & 0,31 \\
5 & $-0,1 \%$ & 0,20 & $0,3 \%$ & $-0,68$ \\
6 & $-0,6 \%$ & $-1,28$ & $-0,3 \%$ & $-0,71$ \\
7 & $0,7 \%$ & $-1,14$ & $1,1 \%$ & 1,28 \\
8 & $-0,8 \%$ & 0,60 & $0,0 \%$ & 0,03 \\
9 & $-0,3 \%$ & $-1,04$ & $-0,1 \%$ & $-0,81$ \\
10 & $1,0 \%$ & 0,91 & $1,1 \%$ & 1,23 \\
\hline
\end{tabular}

Average Abnormal returns over the 21 day event window are shown for each of the two benchmark models. The results are very similar, with a significant negative abnormal return of around $3 \%$ on the announcement, Day 0.

Table 2 shows the results of the event study over the five-day event window. There is a cumulative abnormal return of $-4,5 \%$ and $-3,8 \%$ for the Market Model and the Market Adjusted Returns Model respectively. The cumulative abnormal returns failed normality tests. Leptokurtosis is present in the cumulative abnormal returns, but not abnormal skewness. Parametric and nonparametric tests were therefore conducted. As shown in Table 2 all three tests conducted for statistical significance for both estimation methods show that the cumulative abnormal returns are significant at the $5 \%$ level.

The results from the Market Model and the Market Adjusted Model were examined using a two-tailed paired t-test. It was shown that there was no mean difference in the ACARs at the $5 \%$ significance level. Therefore, only the ACARs of one model, namely the Market Adjusted Returns Model, were used for the rest of the study.
Figure 3 shows the cumulative abnormal returns for the Market Adjusted Returns Model plotted against time. A linear downwards sloping trend line was added to this graph. A quarterly, three-year moving average was also added to this graph. This moving average line has a visible downward trend. This result indicates that the negative market reaction to rights issue announcements has increased over time. Based on this observation, time was included as an independent variable in the multiple regression model.

A correlation matrix revealed that none of the pairs of independent variables in the regression analysis displayed a correlation coefficient in excess of 0,7 or 0,7 .

Table 3 shows the results of the stepwise multiple regression analysis using the ACARs calculated from the Market Adjusted Returns Model and all the standardised economic factors identified in the literature review, as well as 'time'. 
Table 2: The ACARs cumulated over the five-day event window.

\begin{tabular}{lcc}
\hline Model & Market Model & $\begin{array}{c}\text { Market Adjusted } \\
\text { Returns Model }\end{array}$ \\
\hline Sample size & 109 & 109 \\
ACAR & $-4,5 \%$ & $-3,8 \%$ \\
Parametric tests & & \\
Z statistic & $-3,92^{* * *}$ & $-3,20^{* * *}$ \\
Non-parametric tests & & \\
Binomial Z statistic & $5,08^{* * *}$ & $4,12^{* * *}$ \\
Wilcoxon Signed-Rank & $-5,04^{* * *}$ & $-4,37^{* * *}$ \\
\hline
\end{tabular}

*** Significant at the $1 \%$ level

The average cumulative abnormal returns for the five days following the announcement are shown to be significantly different from zero at a negative figure of approximately $-4 \%$.

Table 3 shows that the overall model is significant at the $5 \%$ significance level, and explains $18 \%$ of the variation in the cumulative abnormal returns. Economic growth and interest rate level both have positive coefficients and are statistically significant at the $5 \%$ significance level. The coefficient for stock market performance is negative and statistically significant at the $5 \%$ level. Time and the business cycle proxy both have negative coefficients that are not significant. The business confidence index proxy is positive and is not significant.

The residuals of the multiple regression analysis were found to be heteroscedastic and non-normal. To test for stability and stationarity the samples was randomly split into two, re-analysed and compared with the full sample. A $t$-test revealed that the samples were likely to have been drawn from the same population. Table 3 also shows that the coefficients for the independent variables in the split samples all fall within the coefficient ranges from the full sample. The coefficients of the independent variables all have the same signs as the full sample. Sample A model is significant at the $5 \%$ significance level.

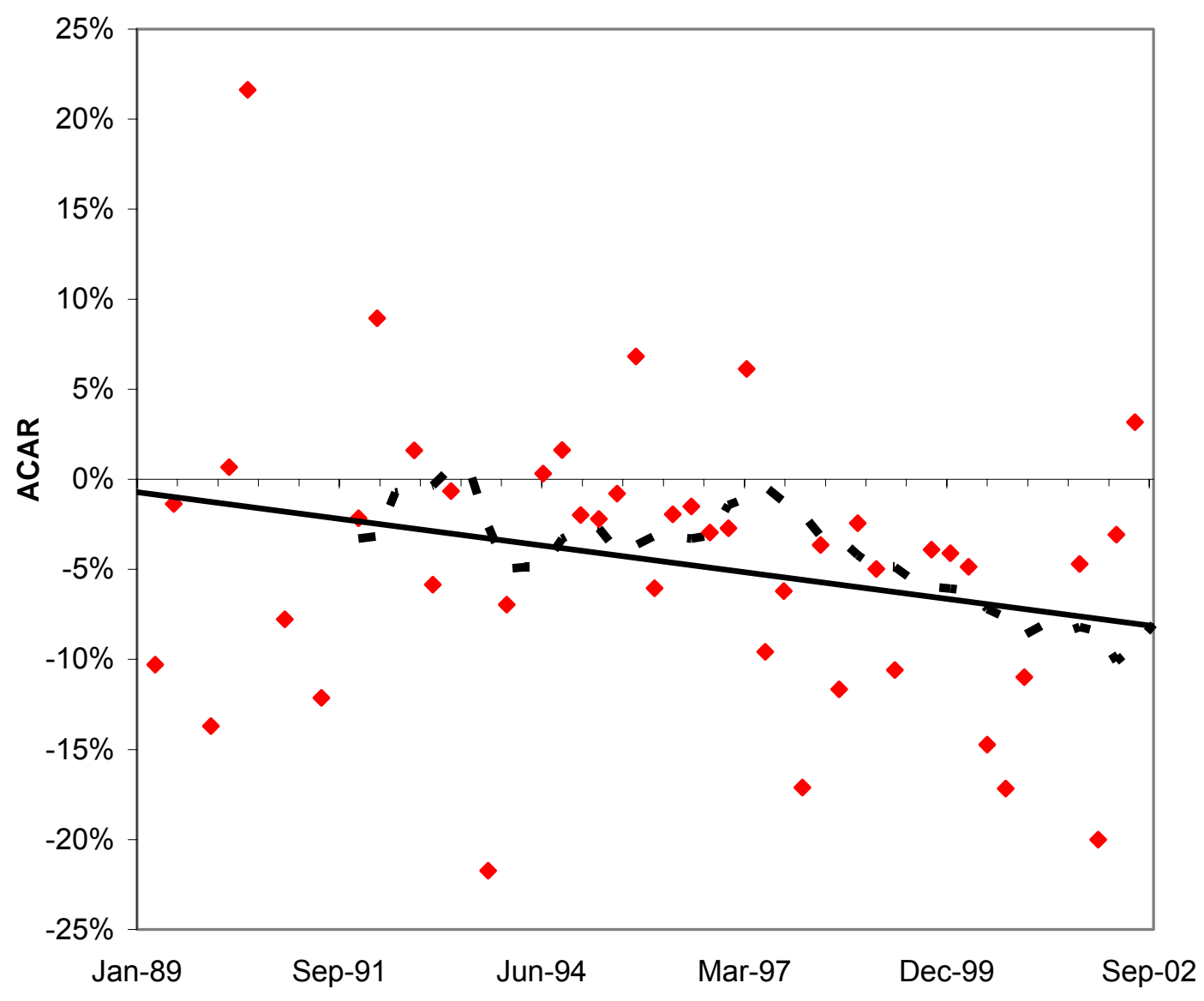

\begin{tabular}{|ll|}
\hline & Quarterly average \\
- & Quarterly 3-year moving average \\
& Linear (Quarterly average) \\
\hline
\end{tabular}

Figure 3: Market model quarterly ACARs over time.

Average cumulative abnormal returns are plotted against time. A downward sloping trend line and a 3 year moving average indicate that the negative market reaction has worsened over time. 
Table 3: Multiple regression results of the full sample and two random samples.

\begin{tabular}{|c|c|c|c|c|c|}
\hline \multirow[t]{3}{*}{ Model } & \multicolumn{3}{|c|}{ Full sample } & \multirow[t]{2}{*}{ Sample A } & \multirow[t]{2}{*}{ Sample B } \\
\hline & \multirow[b]{2}{*}{ Coefficient } & \multicolumn{2}{|c|}{ Coefficient range } & & \\
\hline & & Lower & Upper & Coefficient & Coefficien \\
\hline \multirow[t]{2}{*}{ Intercept } & $-0,0137$ & $-0,0599$ & 0,0326 & $-0,0257$ & $-0,0067$ \\
\hline & $(-0,59)$ & & & & \\
\hline \multirow[t]{2}{*}{$\Delta I N T$} & 0,0287 & 0,0099 & 0,0474 & 0,0282 & 0,0279 \\
\hline & $(2,53)^{\star \star \star}$ & & & $(2,11)^{* *}$ & $(1,90)^{*}$ \\
\hline \multirow[t]{2}{*}{ STOCK } & $-0,0190$ & $-0,0365$ & $-0,0015$ & $-0,0090$ & $-0,0283$ \\
\hline & $(-2,16)^{\star \star}$ & & & $(-0,73)$ & $(-2,13)^{\star \star}$ \\
\hline \multirow[t]{2}{*}{$E C O N$} & 0,0225 & 0,0049 & 0,0402 & 0,0330 & 0,0098 \\
\hline & $(2,53)^{\star *}$ & & & $(2,83)^{\star \star \star}$ & $(0,65)$ \\
\hline \multirow[t]{2}{*}{ CYCLE } & $-0,0073$ & $-0,0273$ & 0,0127 & $-0,0053$ & $-0,0061$ \\
\hline & $(-0,73)$ & & & $(-0,38)$ & $(-0,39)$ \\
\hline \multirow[t]{2}{*}{ CONFI } & 0,0124 & $-0,0070$ & 0,0318 & 0,0081 & 0,0108 \\
\hline & $(1,27)$ & & & $(0,58)$ & $(0,74)$ \\
\hline \multirow[t]{2}{*}{ TIME } & $-9,4 \mathrm{E}-6$ & $-25,9 \mathrm{E}-6$ & $7,1 \mathrm{E}-6$ & $-8,1 \mathrm{E}-6$ & $-10,9 E-6$ \\
\hline & $(-1,13)$ & & & $(-0,74)$ & $(-0,81)$ \\
\hline $\mathrm{R}^{2}$ & 0,225 & & & 0,281 & 0,221 \\
\hline Adjusted $\mathrm{R}^{2}$ & 0,180 & & & & \\
\hline F-ratio & $4,944^{\star \star *}$ & & & $3,121^{\text {** }}$ & $2,2189^{*}$ \\
\hline
\end{tabular}

Note: t-statistics are in parenthesis

*** Significant at the $1 \%$ level

** Significant at the $5 \%$ level

* Significant at the $10 \%$ level

Multiple regression results for the model to predict average cumulative abnormal returns using the independent variables: interest rates, stock market performance, economic growth, the business cycle and business confidence. Economic growth and interest rates showed a positive association whilst stock market performance was negative. A (randomly) split sample was used to test for stability and stationarity.

\section{INTERPRETATION OF RESULTS}

The results of the study show that rights issue announcements do have a statistically significant negative impact on the share price of JSE listed companies. The share price drops approximately $2,8 \%$ on the day of the announcement. Over the five-day event window, the share price on average drops a total of $3,8 \%$ following a rights issue announcement. This is consistent with the findings of international and local research (White and Lusztig, 1980; Asquith and Mullins, 1986; Mikkelson and Partch, 1986; Smith, 1986; Dierkens, 1991; Pilotte, 1992; Youds, Firer and Ward, 1993; Bayless, 1994; Sant and Ferris 1994; Bohren et al., 1997; Bhana, 1998 and Horne, 1999).

The results of this study are consistent with other studies in terms of both magnitude and direction of the share price response. Therefore the null hypothesis of Hypothesis One is rejected and the alternative hypothesis, that the share price response to a rights issue announcement is significantly negative, is accepted.

Economic factors were found to influence the impact that rights issue announcements have on share price returns.

The coefficient of interest rate levels is positive and statistically significant. This shows that when interest rate levels are high the share price response to an announcement of a rights issue is less negative. This result did not accord with the a priori expectation of a negative co-efficient, which might normally be associated with a hot period. The result could reflect 
that firms are being rewarded for choosing to raise equity and not debt in high interest periods.

In their research Madura and Akhigbe (1995) found that the share price response to convertible debt offerings was negative and significantly related to interest rates. They suggested that firms which did not lock themselves into debt at high interest rates were minimising their cost of capital, and would be rewarded for doing so by the market. However, further analysis of this is required.

The coefficient of stock market performance was found to be negative and statistically significant. This finding shows that the greater the increase in the stock market index prior to a rights issue announcement the greater the decline in the share price on the announcement. This is contrary to the expected direction of the relationship, which was based on the findings of Choe et al. (1993), Asquith and Mullins (1986) and Myers and Majluf (1984). However, this finding is consistent with that of Masulis and Korwar (1986).

The coefficient of economic growth is positive and statistically significant. This shows that when economic growth is high the share price response to a rights issue announcement will be less negative. This finding was as expected and consistent with those of Bayless and Chaplinsky (1996) and Choe et al. (1993). This finding also supports the theory that low asymmetric information results in lower negative share price responses to equity announcements (D'Mello and Ferris, 2000; Dierkens, 1991 and Korajczyk et al., 1991). Asymmetric information has been shown by Choe et al. (1993) to be lower in periods of high economic growth. This is consistent with theoretical models of Myers and Majluf (1984) and Lucas and McDonald (1990).

The coefficient of the business cycle was found to be negative and statistically insignificant. Although this is contrary to the literature, it is not unexpected, as business cycles are a broad measure that cover many months with varying economic growth. The more sensitive measure of economic growth (ECON) was tested separately as discussed above, and found to be statistically significant.

The coefficient of business confidence index was found to be positive and statistically insignificant. The direction is as expected, and as it is not significant it supports the findings of Collins (2001) that markets are informationally efficient in terms of the economic fundamentals of the business confidence index, and that stock market performance is a predictor of the business confidence index. This suggests that the business confidence index does not convey any new information to the market that would be considered separately when there is a rights issue announcement.
The coefficient of time is negative and statistically insignificant. This shows that although the share price reaction to rights issue announcements appears to have become increasingly negative over time, there is no statistical support for this observation.

\section{CONCLUSIONS}

This research investigated the relationship between economic factors and the share price response to rights issue announcements. Understanding the influence that economic factors could have impacts on the ability of a firm to raise equity effectively and efficiently.

The negative share price reaction associated with new equity issues was confirmed by using the event study methodology. It was found that there is a statistically significant share price reaction of $-3,8 \%$ on average over the sample for the event window.

The results from the event study were then used in the second part of the study. A multiple regression analysis showed that economic factors do influence the share price response to rights issue announcements. In particular, interest rate levels, economic growth and stock market performance significantly affect this relationship.

Two issues were identified during the course of this study that could be researched in the future. First firmspecific factors could be included in a regression model in order to find a more definitive model for explaining the share price response to rights issue announcements, and secondly the economic proxies used could be refined and optimised.

\section{REFERENCES}

Asquith P and Mullins DW Jr. 1986. Equity issues and offering dilution. Journal of Financial Economics, 15:61-89.

Balduzzi P. 1995. Stock returns, inflation and the 'proxy hypothesis': a new look at the data. Economic Letter, 48:47-53.

Bayless M. 1994. The influence of predictability on differences in the market reaction to debt and equity issue announcements. The Journal of Financial Research, 17(1):117-131.

Bayless M and Chaplinsky S. 1993. Seasoned equity issuance in hot and cold markets. The Journal of Finance, 1062.

Bayless M and Chaplinsky S. 1996. Is there a window of opportunity for seasoned equity issuance? The Journal of Finance, 51(1):253-278.

Bhana N. 1998. Share price reaction to announcements of equity financing by companies 
listed on the Johannesburg Stock Exchange. The Investment Analysts Journal, 48:35-44.

Bohren O, Eckbo BE and Michalsen D. 1997. Why underwrite rights offerings? Some new evidence. Journal of Financial Economics, 46:223-261.

Bowman R. 1983. Understanding and conducting event studies. Journal of Business and Financial Accounting, 10(4):561-584.

Brown SJ and Warner JB. 1985. Using daily stock returns: The case of the event studies. Journal of Financial Economics, 14:3-31.

Chen N, Roll R and Ross SA. 1986. Economic forces and the stock market. Journal of Business, 56: 383403.

Choe H, Masulis, RW and Nanda V. 1993. Common stock offerings across the business cycle. Journal of Empirical Finance, 1:3-33.

Collins D. 2001. The relationship between business confidence surveys and stock market performance. The Investment Analysts Journal, 54: 9-17.

Daniel K and Titman S. 1997. Evidence on the characteristics of cross sectional variation in stock returns. The Journal of Finance, 52:1-33.

Dierkens N. 1991. Information asymmetry and equity issues. Journal of Financial and Quantitative Analysis, 26:181-199.

D'Mello R and Ferris SP. 2000. The information effects of analyst activity at the announcement of new equity issues. Financial Management, 29(1):78-95.

Downes DH and Heinkel R. 1982. Signalling and valuation of unseasoned new issues. Journal of Finance, 37(1):1-10.

Fama EF and French KR. 1992. The cross-section of expected stock returns. The Journal of Finance, 47(2):427-465.

Fama EF and French KR. 1996. Multifactor explanations of asset pricing anomalies. The Journal of Finance, 51(1):55-84.

Gjerde O and Saettem F. 1999. Causal relations among stock returns and macroeconomic variables in a small open economy. Journal of International Financial Markets, Institutions and Money, 9(1):61-74.

Hansen RS and Crutchley C. 1990. Corporate earnings and financings: An empirical analysis. Journal of Business, 63:347-71.
Harvey CR and Haung RD. 1991. Volatility in the foreign currency futures markets. The Review of Financial Studies, 4(3):543-569.

Henn $J$ and Smit EvdM. 1997. The influence of economic news events on share market activity in South Africa. The Investment Analysts Journal, 46:2334.

Horne L. 1999. The timing of rights issues on the Johannesburg Stock Exchange. Unpublished MBA Research Report, Johannesburg: University of the Witwatersrand.

Jensen MC and Meckling W. 1976. Theory of the firm: Managerial behaviour, agency costs and ownership structure. Journal of Financial Economics, 3:305-360.

Korajczyk R, Lucas D and McDonald R. 1991. The effect of information releases on the pricing and timing of equity issues. Review of Financial Studies, 4:685708.

Korajczyk RA and Levy A. 2001. Capital structure choice: Macroeconomic conditions and financial constraints. Working Paper \#279. [http://www.Kellogg.nwu.edu/faculty/korajczy/htm/wp27 9.pdf], (accessed 20 December 2002).

Lee B. 1992. Causal relations among stock returns, interest rates, real activity, and inflation. Journal of Finance, 47(4):1591-1603.

Lucas D and McDonald R. 1990. Equity issues and stock price dynamics. Journal of Finance, 45: 10191044.

Madura $\mathrm{J}$ and Akhigbe A. 1995. Influence of economic factors on the valuation effects of debt offerings. Applied Economics, 27:907-915.

Marsh P. 1982. The choice between equity and debt: An empirical study. Journal of Finance, 37: 121-44.

Masulis RW and Korwar AN. 1986. Seasoned equity offerings - An empirical investigation. Journal of Financial Economics, 15:91-118.

McConnell JJ and Muscarella CJ. 1985. Corporate capital expenditure decisions and the market value of the firm. Journal of Financial Economics, 14:399-422.

McWilliams A and Siegel D. 1997. Event studies in management research: Theoretical and empirical issues. Academy of Management Journal, 40(3):626657.

McWilliams TP and McWilliams VB. 2000. Another look at theoretical and empirical issues in event study methodology. The Journal of Applied Business Research, 16(3):1-11. 
Mikkelson WH and Partch MM. 1986. Valuation effects of security offerings and the issuance process. Journal of Financial Economics, 15:31-60.

Miller M and Rock K. 1985. Dividend policy under asymmetric information. Journal of Finance, 40(3):1031-1050.

Mordant N. 2002. Profitability of directors' dealings. Unpublished MBA Research Report, Johannesburg: University of the Witwatersrand.

Myers S and Majluf NS. 1984. Corporate investment and financing decisions when firms have information that investors do not have. Journal of Financial Economics, 13:187-221.

Mutooni RN. 2001. Equity style timing on the Johannesburg Stock Exchange. Unpublished MBA Research Report, Johannesburg: University of the Witwatersrand.

Nofsinger JR. 2001. The impact of public information on investors. Journal of Banking and Finance, 25:1339-1366.

Pilotte E. 1992. Growth opportunities and the stock price response to new financing. Journal of Business, 65:371-394.

Sant R and Ferris S. 1994. Seasoned equity offerings: The case of all-equity firms. Journal of Business Finance and Accounting, 45(2):429-444.

Smith C. 1986. Investment banking and the capital acquisition process. Journal of Financial Economics, 15:3-29.

Taggart RA Jr. 1977. A model of corporate financing decisions. Journal of Finance, 32:1467-1484.

Van Rensberg P. 1999. Macroeconomic identification of candidate APT factors on the Johannesburg Stock Exchange. Journal of Studies in Economics and Econometrics, 23(2):27-53.

Van Rensberg P. 2001. A decomposition of stylebased risk on the JSE. The Investment Analysts Journal, 54:45-60.

White RW and Lusztig PA. 1980. The price effects of rights offerings. Journal of Financial and Quantitative Analysis, 15(1):25-40.

Youds D, Firer C and Ward M. 1993. The impact of rights issue announcements on share prices. Journal for Studies in Economics and Econometrics, 17(3):2140. 